\title{
AKADEMICKIE CZASOPISMA INFORMACYJNE W KATALOGACH OPAC, BIBLIOTEKACH CYFROWYCH I NA STRONACH WWW BIBLIOTEK WYŻSZYCH UCZELNI TECHNICZNYCH
}

\begin{abstract}
Academic magazines constitute a separate specific group of titles in the offer of academic libraries. Librarians join in their electronic publishing and university publishers assume the long-term archiving of digital resources. New trends in publishing academic magazines and a reduction in printed resources can be observed. Some titles cannot be shown in the library OPAC. There is a need for information about online resources. This article attempts to answer the question how the offer of academic magazines is presented in OPACs, digital libraries and on the library websites of selected technical universities in Poland. Attention was paid to the resources available online. In order to determine how the information about magazines in print and online is developed, the title published at a particular university as well as those titles issued by other universities in their catalogues were considered. The review of the above mentioned sources was made in the period July-September 2014.
\end{abstract}

Słowa kluczowe: akademickie czasopisma informacyjne, biblioteki wyższych uczelni technicznych, OPAC, biblioteki cyfrowe

Rozwój zasobów ogólnie dostępnych i nowoczesnych źródeł informacji sprzyjają sprawnej komunikacji i dzieleniu się wiedzą. Bibliotekarze aktywnie włączają się w ten proces, a starania te znajdują odzwierciedlenie w ofercie bibliotek. Szczególne miejsce w kolekcji bibliotek zajmują akademickie czasopisma informacyjne (ACI). Stanowią one oddzielną specyficzną grupę tytułów wśród czasopism uczelnianych. Wynika to z przekazu treści i zawartości merytorycznej. Obok tradycyjnych wersji drukowanych pojawiły się zasoby elektroniczne udostępniane głównie na stronach poszczególnych uczelni oraz na platformach bibliotek cyfrowych. W ostatnim czasie wydawcy uczelniani przejmują długoterminowe archiwizowanie zasobów cyfrowych. Obserwuje się nowe trendy w publikowaniu ACI w Internecie. W związku z tym zmniejszają się zasoby drukowane $\mathrm{w}$ bibliotekach, niektóre tytuły nie mogą zostać opracowane w katalogu komputerowym biblioteki. Kolekcja podlega ciągłym zmianom.

$\mathrm{W}$ artykule podjęto próbę przedstawienia oferty bibliotek w zakresie czasopism informacyjnych wydawanych przez uczelnie techniczne. W okresie lipiec-wrzesień 2014 r. dokonano przeglądu czasopism na stronach WWW 
bibliotek wybranych wyższych uczelni technicznych w Polsce, według kryteruim ich obecności w serwisach bibliotecznych. Szczególną uwagę zwrócono na zasoby dostępne online. Badaniem objęto trzy różne źródła informacji tworzone przez bibliotekarzy: katalog komputerowy (OPAC), biblioteka cyfrowa, czasopisma linkowane na stronie WWW biblioteki.

\section{Przesłanki podjęcia problemu badawczego}

Istniało kilka przesłanek podjęcia problemu badawczego w niniejszej pracy. Jedną stanowiło rozpoznanie zmian w udostępnianiu czasopism w bibliotekach naukowych na przykładzie akademickich czasopism informacyjnych; drugą - wyjaśnienie przyczyn konieczności modyfikacji działalności informacyjnej bibliotek $\mathrm{w}$ ramach nowych zadań związanych $\mathrm{z}$ wprowadzeniem materiałów dostępnych online. Udostępnianie czasopism w bibliotece łączy się $\mathrm{z}$ informacją o czasopismach w katalogach komputerowych, bibliotekach cyfrowych i na stronie internetowej biblioteki.

Wybór akademickich czasopism informacyjnych jako materiału badawczego nie był przypadkowy. W ofercie uczelni cyfrowe archiwa otwarte są rozproszone $\mathrm{w}$ Internecie, a wersje drukowane dystrybuowane bezpłatnie przez większość instytucji. Biblioteki pozyskują tytuł wydawany w macierzystej uczelni przede wszystkim bezpośrednio od wydawnictw uczelnianych lub dziatu promocji, natomiast tytuły wydawane przez uczelnie inne od bibliotek i/lub od wydawnictw uczelnianych, działu promocji tychże uczelni.

W kolekcji bibliotecznej ACI stanowią specyficzną grupę tytułów. Ze względu na sposób przekazu treści i zawartość merytoryczną wyróżniają się wśród innych czasopism uczelnianych. Zawierają one sprawozdania, wywiady, komentarze, felietony, proste informacje prasowe, coraz częściej multimedia charakterystyczne dla prasy internetowej, co powoduje, że publikacje te pomijane są w profesjonalnych serwisach, takich jak: Arianta - Naukowe i Branżowe Polskie Czasopisma Elektroniczne, BazTech - Baza Danych o Zawartości Polskich Czasopism Technicznych, Biblioteka Nauki Centrum Otwartej Nauki, Directory of Open Access Journals, wykazy czasopism Open Access oraz wykazy czasopism uczelnianych sporządzone przez bibliotekarzy na stronach WWW bibliotek.

$\mathrm{Na}$ specyfikę ACI składa się także tematyka skoncentrowana przede wszystkim na jednej uczelni. Dokumentacja życia uczelni stanowiąca misję czasopisma wyznacza dobór materiałów do publikacji. Jako jedno z narzędzi promocji uczelni rejestrują wiadomości z zakresu historycznych i bieżących wydarzeń mających miejsce na uczelni, sprawy związane z uczelnią i szkolnictwem wyższym, awanse pracowników uczelni. Są specyficznym, cennym źródłem informacji o bibliotekach wyższych uczelni technicznych. Można w nich przeczytać między innymi o: początkach komputeryzacji w Polsce ${ }^{1}$, rozwoju

${ }^{1}$ Zob.: Co nowego w... Bibliotece, oprac. E.R., „Życie Uczelni. Biuletyn Informacyjny Politechniki Łódzkiej” 1996, nr 40, s. 5; I. Pawelec, H. Celoch, Biblioteka Gtówna, „Biuletyn 
specjalistycznych serwisów tworzonych przez bibliotekarzy ${ }^{2}$, adaptacji bibliotek do nowych warunków funkcjonowania w nowopowstałych budynkach bibliotecznych ${ }^{3}$. Zawartość obszernych wiadomości o bibliotekach powoduje, że obok czasopism fachowych pełnią funkcję informacyjną i edukacyjną w dziedzinie rozwoju bibliotekarstwa polskiego.

\section{Stan badań}

Pomimo tego, że duża liczba publikacji w literaturze przedmiotu jest poświęcona tematyce dokumentów w katalogach komputerowych, bibliotekach cyfrowych i na stronach WWW bibliotek, to niewiele $\mathrm{z}$ nich przedstawia sensu stricto czasopisma informacyjne uczelni wyższych. Jednak analiza kolekcji czasopism w różnych bibliotekach dostarcza wiedzy na temat ich udostępniania.

W początkowym okresie budowania otwartych zasobów współczesnych czasopism uczelnianych, Marek Nahotko mówiąc „o uruchomieniu zasadniczej transformacji w sposobach publikowania, której efektem będą nowe możliwości i nowe produkty zmieniające praktykę wydawniczą," ${ }^{4}$, rozważania koncentruje na naukowych czasopismach elektronicznych dostępnych w Internecie. Autor zwraca uwagę na zmiany zachodzące w bibliotekach, pisząc, że: „Tworzenie nowych schematów metadanych (...) jest odzwierciedleniem zmiany praktyki katalogowania w kierunku nowego pojmowania opisu i udostępniania treści ${ }^{5}$.

W innych publikacjach, cyfrowe kolekcje czasopism zanalizowano pod różnym kątem, także w serwisach: katalogi komputerowe, biblioteki cyfrowe, strony WWW bibliotek, które objęto badaniem w niniejszej pracy. W katalogach komputerowych polskich bibliotek zbadano rekordy dokumentów

Informacyjny Politechniki Lubelskiej” 1997, nr 1, s. 36; H. Ganińska, Co nowego w Bibliotece Głównej, „Głos Politechniki. Pismo Politechniki Poznańskiej” 1997, nr 2-3, s. 12-13; H. Szarski, Komputeryzacja systemu biblioteczno-informacyjnego PWr, „Pryzmat. Pismo Informacyjne Politechniki Wrocławskiej” 2003, nr 171, s. 46-47; L. Szczygłowska, Komputeryzacja Biblioteki Głównej Politechniki Częstochowskiej w systemie APIS-ZB, „Politechnika Częstochowska” 2000, nr 13, s. 9-11.

${ }^{2}$ Zob.: J. Gajda, Biblioteka Politechniki Lubelskiej. Milion dokumentów w polskich bibliotekach cyfrowych, „Biuletyn Informacyjny Politechniki Lubelskiej” 2012, nr 2 (30), s. 16-17; A. Narloch, J. Skrodzka, BazTech - baza indeksujaca polskie czasopisma z zakresu nauk technicznych, „Forum Uczelniane. Pismo Zachodniopomorskiego Uniwersytetu Technologicznego w Szczecinie" 2014, nr 3 (23), s. 26-28.

${ }^{3}$ Zob.: I. Piwońska, A. Peszel, Koniec wieńczy dzieło, „Głos Akademicki Wojskowej Akademii Technicznej” 2014, nr 1 (214), s. 40; Nowe oblicze Biblioteki Głównej AGH. Temat wydania, „Biuletyn AGH” 2014, nr 75, s. 2, 4-15; Biblioteka bez papierowej ksiazki, ale innych tu nie braknie, „Pryzmat. Wiadomości Politechniki Wrocławskiej” 29.04.2014, Aktualizacja: 07.05.2014 16:33, [dostęp: 15.08.2014], http://www.pryzmat.pwr.edu.pl/wiadomosci/702.

\footnotetext{
${ }^{4}$ M. Nahotko, Naukowe czasopisma elektroniczne, Warszawa 2007, s. 15.

${ }^{5}$ Ibidem, s. 152.
} 
ze szczególnym uwzględnieniem informacji o zasobach znajdujących się w bibliotekach cyfrowych i ustalono, że wśród bibliotek publicznych, uniwersyteckich, ekonomicznych, AWF, rolniczych, teologicznych i artystycznych, najwięcej informacji zamieściły biblioteki uczelni technicznych ${ }^{6}$. W katalogach bibliotek uczelni technicznych znaleziono sposoby udostępniania informacji o ogólnodostępnych zasobach w Internecie z poziomu skatalogowanego czasopisma drukowanego i wyróżniono między innymi biblioteki posiadające katalogi z aktywnym odsyłaczem dostępnym w każdym opracowanym czasopiśmie?

Poprzez analizę czasopism medycznych w wybranych pięciu bibliotekach cyfrowych pokazano, jak dużym zainteresowaniem cieszą się zasoby cyfrowe bibliotek w Internecie. Odnotowano siedem najbardziej popularnych publikacji: „Advances in Clinical and Experimental Medicine” Vol. 15, 2006, nr 1, „Repetytorium z rozwoju człowieka”, „Advances in Clinical and Experimental Medicine" Vol. 16, 2007, nr 1, ,Advances in Clinical and Experimental Medicine" Vol. 15, 2006, nr 4, "Multimodal image processing in cytology", "Advances in Clinical and Experimental Medicine" Vol. 15, 2006, nr 2, „Advances in Clinical and Experimental Medicine” Vol. 14, 2005, $\mathrm{nr} 5^{8}$. W Dolnośląskiej Bibliotece Cyfrowej, przedstawiono udostępnione dla wszystkich kolekcje, między innymi tytuły czasopism naukowych przede wszystkim uczelnianych: „Cuprum”, ,Journal of Energy Science”, „Materials Science Poland”, „Wiadomości Chemiczne”, „Śląski Przegląd Statystyczny”, „Argumenta Oeconomica”, „Zeszyty Naukowe Uniwersytetu Przyrodniczego we Wrocławiu”, „'Zeszyty Wydziału Humanistycznego”, „Colloquium Salutis”, „Wrocławski Przegląd Techniczny”, „Advances in Clinical and Experimental Medicine”, „Dental and Medical Problems”, „Polimery w Medycynie”, „Z Problemów Bibliotek Naukowych Wrocławia” oraz ACI „Format - pismo artystyczne" tylko $2006 \mathrm{nr} 50(2-3)^{9}$.

W różnych bibliotekach cyfrowych rozpatrywano sposób prezentacji czasopism wydanych przed II wojną światową. Przedstawiono między innymi: różne struktury czasopism w różnych bibliotekach, to znaczy podział na roczniki numery, roczniki/woluminy publikowane w całości jako elementy publikacji grupowej; brak konsekwencji w jednym serwisie (jednej bibliotece),

${ }^{6}$ I. Swoboda, R. Frączek, Dokumenty elektroniczne w OPAC bibliotek polskich. Komunikat z badań, „PTINT Praktyka i Teoria Informacji Naukowej i Technicznej” 2009, T. 17, nr 4 (68), s. 32, 34.

${ }^{7}$ U. Knop, Polskie czasopisma ogólnodostępne online w katalogach OPAC i na stronach WWW bibliotek wyższych uczelni technicznych - rozpoznanie wstępne, „Bibliotheca Nostra” 2014, nr 1 (35), s. 66-68.

${ }^{8}$ R. Rohleder, Konsorcjum DBC - wspótpraca bibliotek przy tworzeniu kolekcji cyfrowych, zbiory medyczne, „Forum Bibliotek Medycznych” 2010, R. 3, nr 2 (6), s. 217.

${ }^{9}$ A. Wałek, Biblioteka cyfrowa jako typ otwartego repozytorium (na przyktadzie Dolnośląskiej Biblioteki Cyfrowej), [w:] Otwarte zasoby wiedzy. Nowe zadania uczelni i bibliotek w rozwoju komunikacji naukowej. Materiały konferencyjne, Kraków-Zakopane, 15-17 czerwca 2011, Kraków 2011, s. 130-132. 
na przykład jeden tytuł z podziałem na roczniki/numery, a inny dzielony tylko na roczniki; rodzaje powiązań - z dodatkami, innymi tytułami, katalogiem bibliotecznym; propozycję Jagiellońskiej Biblioteki Cyfrowej dotyczącą stworzenia struktury czasopisma i dodatków do czasopisma na przykładzie „Gazety Lwowskiej” - opis publikacji grupowej dla całego tytułu, szczegółową strukturą (rekord zasobu), opis pojedynczego rocznika, opis „Dodatki do Gazety Lwowskiej”, opis dodatku ${ }^{10}$.

Coraz częściej użytkownicy korzystają z bibliotecznych kolekcji online, w związku z tym ich pozytywne opinie są uzależnione od prezentacji czasopism na stronie WWW biblioteki. W oparciu o wyniki audytu użyteczności serwisów bibliotecznych stron bibliotek przeprowadzonego przez Laboratorium EDISONDA w Krakowie w 2010 r., przedstawiono czynniki wpływające na funkcjonalności i poprawność konstruowania strony głównej, podstron, prezentacji treści, zwracając jednocześnie uwagę na rozwój usług Biblioteki Web 2.0, dającej użytkownikom nowoczesne technologie i narzędzia do współtworzenia zasobów biblioteki ${ }^{11}$.

Na stronach niektórych bibliotek znajdują się wykazy czasopism drukowanych oraz wykazy czasopism linkowanych. W wyniku analizy polskich czasopism ogólnodostępnych wskazano wykazy pojedynczych linkowanych tytułów sporządzone przez bibliotekarzy na stronach WWW bibliotek wybranych wyższych uczelni technicznych ${ }^{12}$.

Współczesne biuletyny i pisma informacyjne są jedynie sygnalizowane w bibliotece cyfrowej. Zwrócono uwagę na potrzebę ich udostępniania w serwisie, ponieważ są doskonałym materiałem źródłowym na potrzeby prac naukowych w ujęciu historycznym ${ }^{13}$.

Do najważniejszych publikacji, w których znajduje się wykaz czasopism informacyjnych wydawanych przez uczelnie polskie należą: opracowania bibliograficzne za lata $1989-2012^{14}$ i $2012^{15}$ r. oraz zestawienie tematyczne „O bibliotece” opracowane na podstawie czasopisma informacyjnego Politechniki Poznańskiej „Głos Politechniki”16. Istotne znaczenie z punktu widzenia

${ }^{10}$ P. Myszkowski, L. Szafrański, Sposób prezentacji czasopisma w bibliotece cyfrowej, [w:] Opracowanie czasopism ukazujacych się przed II wojna światowa w kontekście ich publikacji w bibliotece cyfrowej. Konferencja, Kraków, Biblioteka Jagiellońska, 17 listopada 2011 r., [dostęp: 15.08.2014], http://jbc.bj.uj.edu.pl/dlibra/publication?id=92556\&from=\&dirids=1\&tab $=1 \& 1 \mathrm{p}=1 \& \mathrm{QI}=$.

${ }^{11}$ Zob.: A. Wałek, Strony WWW bibliotek jako element promocji i narzędzie komunikacji z użytkownikiem, „Fides. Biuletyn Bibliotek Kościelnych” 2014, nr 1 (38), s. 109-118.

${ }^{12}$ U. Knop, op. cit., s. 69-70.

${ }^{13}$ A. Wałek, op. cit., s. 132.

${ }^{14}$ A. Strumiłło, Bibliografia czasopism akademickich o profilu informacyjnym (19892012), „Forum Bibliotek Medycznych” 2012, R. 5, nr 1 (9), s. 591-624.

${ }^{15} \mathrm{~K}$. Jarkiewicz, Informator o Redakcjach gazet akademickich w 2012 roku, „Forum Bibliotek Medycznych" 2012, R.5, nr 1 (9), s. 547-590.

${ }^{16}$ H. Nowicka, O czym piszemy w , Gtosie Politechniki”. Artykuty i informacje bibliotekarzy PP w latach 1995-2007, Poznań 2008, 2 s., (Zapiski Biblioteki Głównej Politechniki Poznańskiej; nr 14), [dostęp: 15.08.2014], http://library.put.poznan.pl/doc/publik/zapiski/zapiski14.html. 
wartości użytkowej tych publikacji mają dane na temat czasopism zamieszczone w dwóch pierwszych publikacjach oraz linkowane opisy bibliograficzne odsyłające do ich pełnych tekstów - w zestawieniu tematycznym.

\section{Organizacja badań}

W kontekście zmieniających się warunków funkcjonowania bibliotek podjęto próbę uzyskania odpowiedzi na pytanie jak przedstawia się oferta biblioteczna w zakresie akademickich czasopism informacyjnych. Dokonano przeglądu katalogów komputerowych, bibliotek cyfrowych i czasopism linkowanych na stronach WWW bibliotek wybranych wyższych uczelni technicznych w Polsce: 13 politechnik ${ }^{17}$, AGH w Krakowie, Akademii TechnicznoHumanistycznej (ATH) w Bielsku-Białej, Uniwersytetu Technologiczno -Humanistycznego im. Kazimierza Pułaskiego (UTH) w Radomiu, Uniwersytetu Technologiczno-Przyrodniczego (UTP) w Bydgoszczy, Uniwersytetu Zielonogórskiego (UZ), Wojskowej Akademii Technicznej (WAT) w Warszawie, Zachodniopomorskiego Uniwersytetu Technologicznego (ZUT) w Szczecinie. Warunkiem doboru biblioteki do badania było posiadanie katalogu komputerowego czasopism. W wyżej wymienionych źródłach zbadano 20 tytułów wybranych z oferty wydawniczej macierzystej uczelni każdej badanej biblioteki. Uwzględniono jeden tytuł ostatnio publikowany. Celem ustalenia oferty sformułowano pytania szczegółowe:

- ile bibliotek wykazuje tytuł publikowany w macierzystej uczelni, a ile tytuły innych uczelni w swoim katalogu komputerowym;

- $\quad$ które tytuły są rozpoznawalne w katalogach innych bibliotek;

- $\quad$ jak przedstawia się oferta zasobów drukowanych i online w katalogu każdej biblioteki;

- $\quad$ jak przedstawia się oferta akademickich czasopism informacyjnych poszczególnych bibliotek w bibliotece cyfrowej;

- $\quad$ w ilu bibliotekach tytuły są linkowane bezpośrednio na stronie WWW biblioteki i jak wygląda oferta zasobów.

Analizie poddano następujące tytuły czasopism: „Akademia. Pismo Akademii Techniczno-Humanistycznej w Bielsku-Białej’, „Biuletyn AGH. Magazyn Informacyjny Akademii Górniczo-Hutniczej”, „Biuletyn Informacyjny Politechniki Lubelskiej”, „Biuletyn Politechniki Śląskiej”, „Biuletyn Politechniki Warszawskiej”, „Format UTP. Kwartalnik Uniwersytetu TechnologicznoPrzyrodniczego w Bydgoszczy”, „Forum Uczelniane. Pismo Zachodniopomorskiego Uniwersytetu Technologicznego w Szczecinie”, "Głos Akademicki Wojskowej Akademii Technicznej. Pismo Pracowników i Studentów”, „Głos Politechniki. Pismo Politechniki Poznańskiej”, „Indeks. Pismo Politechniki

${ }^{17}$ Od 1 stycznia 2014 r. Biblioteka i Ośrodek Informacji Naukowo-Technicznej Politechniki Wrocławskiej funkcjonuje jako Centrum Wiedzy i Informacji Naukowo-Technicznej Politechniki Wrocławskiej, w niniejszej pracy ujęte w grupie bibliotek politechnik. 
Świętokrzyskiej w Kielcach”, „Na Temat. Pismo Politechniki Koszalińskiej”, „Nasza Politechnika. Miesięcznik Politechniki Krakowskiej im. Tadeusza Kościuszki”, „Pismo PG. Forum Społeczności Akademickiej”, „Politechnika Częstochowska. Pismo Środowiska Akademickiego”, „Pryzmat. Pismo Informacyjne Politechniki Wrocławskiej”, „Uniwersytet Zielonogórski. Miesięcznik Społeczności Akademickiej”, „Wiadomości Uczelniane Politechniki Opolskiej”, Z Życia Uniwersytetu. Czasopismo Uniwersytetu TechnologicznoHumanistycznego im. Kazimierza Pułaskiego w Radomiu”, „Życie Politechniki. Pismo Politechniki Białostockiej”, „Życie Uczelni. Biuletyn Informacyjny Politechniki Łódzkiej”.

W katalogu każdej biblioteki wyszukiwano tytuł macierzystej uczelni, następnie tytuły publikowane przez uczelnie inne. Ponadto badano informację o zasobach online w polu 856.

Ofertę elektronicznych zasobów dostępnych w bibliotekach cyfrowych ustalono po wcześniejszym rozpoznaniu uczestnictwa poszczególnych bibliotek $\mathrm{w}$ projekcie biblioteki cyfrowej, $\mathrm{w}$ rezultacie wyszukiwania: obecności zakładki/linku biblioteki cyfrowej i przeglądu informacji o zbiorach bibliotecznych na stronie WWW biblioteki oraz danych w wykazie instytucji wspóltworzących projekt $\mathrm{w}$ regionalnej bibliotece cyfrowej i serwisie FBC. W wyniku włączenia zasobów biblioteki cyfrowej w repozytorium ${ }^{18}$, w Bibliotece Politechniki Krakowskiej tytuł wyszukiwano w repozytorium uczelnianym. W celu uzyskania poprawności wyników kwerendę powtórzono w serwisie FBC.

Na stronach WWW każdej biblioteki badano tylko ofertę w wersji online (tytuły linkowane).

\section{Wyniki badań i ich dyskusja}

W wyniku przeglądu katalogów komputerowych ustalono, że biblioteki opracowują tytuł publikowany w macierzystej uczelni w wersji drukowanej. Ogółem osiemnaście bibliotek wykazuje własne ACI, w dwóch brak takiego tytułu w zasobach. Od 2013 r. dwa nowe tytuły „Biuletyn Politechniki Warszawskiej” i „Z Życia Uniwersytetu. Czasopismo Uniwersytetu Technologiczno-Humanistycznego im. Kazimierza Pułaskiego w Radomiu" nie wpływają do bibliotek. Publikowane wyłącznie w wersji elektronicznej zostały udostępnione:

- $\quad$ pierwszy w postaci portalu internetowego na stronie uczelni, bez podziału na roczniki, numery, w którym nowe wiadomości dodawane są na zasadzie uzupełniania (aktualizacji) strony z datą dzienną i godziną dodania;

- $\quad$ drugi w formie plików PDF.

${ }^{18}$ Bibliotek@Cyfrowa Politechniki Krakowskiej, [dostęp: 15.08.2014], http://www.bib los.pk.edu.pl/bc. 
Tytuły ACI dostępne online w całym cyklu wydawniczym nie są opracowywane w katalogu. Z kolei tytuły ujęte w nim mogą być tylko częściowo dostępne w bibliotece w wersji drukowanej. Dlatego w opisach należy zwracać uwagę na zasoby i ewentualne braki.

Na podstawie analizy roczników i w ich obrębie numerów zarejestrowanych w katalogu komputerowym stwierdzono kompletną kolekcję tylko w piętnastu bibliotekach. Nie odnotowano bieżących numerów tytułów: „Na Temat. Pismo Politechniki Koszalińskiej” (ostatni wpływ 2012 nr 50), „Wiadomości Uczelniane Politechniki Opolskiej" (ostatni wpływ 2013 nr $237+$ nr spec.), „Pryzmat. Wiadomości Politechniki Wrocławskiej” (ostatni wpływ 2013 $\mathrm{nr} 260)$. Z danych katalogowych wynika, że czasopismo w Politechnice Koszalińskiej ukazuje się nadal (jest w kontynuacji), lecz nie odnotowano informacji o brakujących rocznikach 2013 i 2014.

Sposobem ułatwiającym wyszukanie pojedynczych tekstów oraz lokalizację czasopisma w Internecie są aktywne linki do jego archiwum w wersji online. W katalogach bibliotek zamieszczono odsyłacze kierujące do zasobów dostępnych: na stronie internetowej uczelni lub wydawnictwa (Politechnika Białostocka, Politechnika Gdańska, Politechnika Poznańska, Politechnika Śląska, WAT w Warszawie, ZUT w Szczecinie), na stronie biblioteki cyfrowej (Politechnika Lubelska, Politechnika Łódzka), na stronach biblioteki cyfrowej i uczelni (Politechnika Wrocławska), na stronie biblioteki (Politechnika Świętokrzyska).

W przypadku tytułu „Pryzmat. Wiadomości Politechniki Wrocławskiej” występują dwa linki, które odsyłają:

- $\quad$ pierwszy do zasobów w Dolnośląskiej Bibliotece Cyfrowej;

- drugi do zasobów publikowanych jako kontynuacja online na stronie uczelni, w formie portalu internetowego. Nie ma w nim podziału na roczniki czy numery.

Dzięki odsyłaczom można zlokalizować i przeglądać pełne teksty zasobów online, które są dostępne w bibliotece w wersji drukowanej i których brak.

Dokonując porównania zasobów drukowanych i cyfrowych polecanych w katalogach, ustalono niekompletne archiwum elektroniczne tytułów: „Głos Politechniki. Pismo Politechniki Poznańskiej” dostępne w bibliotece w wersji drukowanej od 1994 r., online na stronie uczelni od 2008 r., „Głos Akademicki Wojskowej Akademii Technicznej" w bibliotece w wersji drukowanej od 1997 r., online na stronie uczelni od 2003 r., „Pismo PG. Forum Społeczności Akademickiej" w bibliotece w wersji drukowanej od 1993 r., online na stronie uczelni: lata 1993-2012 w postaci spisu treści. Uczelnia udostępnia wybrane pełne teksty z tych roczników, pełne archiwum od $2013 \mathrm{r}$.

Odmiennie kształtują się $\mathrm{w}$ bibliotekach zasoby czasopism wydawanych przez inne uczelnie. Zarejestrowano je tylko w jedenastu katalogach, natomiast w dziewięciu brak informacji. Biblioteki posiadają: Politechnika Świętokrzyska - 9 tytułów, Politechnika Poznańska 7, Politechnika Opolska 6, Politechnika 
Łódzka 4, AGH 3, UTP w Bydgoszczy 3, ZUT w Szczecinie 2, Politechnika Białostocka 1, Politechnika Śląska 1, Politechnika Warszawska 1, ATH w Bielsku-Białej 1.

Na podstawie analizy danych ustalono w ilu bibliotekach zarejestrowano w katalogu komputerowym następujące tytuły: „Pismo PG. Forum Społeczności Akademickiej” - 8, „Politechnika Częstochowska. Pismo Środowiska Akademickiego” - 6, „Wiadomości Uczelniane Politechniki Opolskiej” - 6, „Nasza Politechnika. Miesięcznik Politechniki Krakowskiej im. Tadeusza Kościuszki” - 4, „Uniwersytet Zielonogórski. Miesięcznik Społeczności Akademickiej” - 4, „Na Temat. Pismo Politechniki Koszalińskiej” 3, „Pryzmat. Wiadomości Politechniki Wrocławskiej” - 2, ,Życie Uczelni. Biuletyn Informacyjny Politechniki Łódzkiej” - 2, „Akademia. Pismo Akademii Techniczno-Humanistycznej w Bielsku-Białej” - 1, „Biuletyn AGH. Magazyn Informacyjny Akademii Górniczo-Hutniczej” - 1, „Życie Politechniki. Pismo Politechniki Białostockiej" -1 .

W tym aktywne linki do wersji elektronicznych ACI na stronie uczelni zamieszczono w opisie (pole 856) w przypadku tytułów „Pismo PG. Forum Społeczności Akademickiej” i „Wiadomości Uczelniane Politechniki Opolskiej”. W przypadku pierwszego tytułu zasób udostępniono w sześciu bibliotekach, w drugim tylko w jednej .

W poszczególnych bibliotekach okres przechowywania czasopism jest różny. Większość z nich nie stanowi przedmiotu inwentaryzacji i przechowywane są przez krótki okres czasu: ostatnie trzy lata $(\mathrm{AGH})$, pięć lat (Politechnika Łódzka). W niektórych bibliotekach informacja katalogowa zawiera tylko opis bibliograficzny bez danych o zasobie. W innych z kolei kolekcje są niepełne, obejmują na przykład tylko dwa lata, zawierają liczne braki. Dostępne dane obejmują przede wszystkim roczniki archiwalne. Natomiast wpływy bieżące (2014) kilku tytułów wyszczególniono tylko w pojedynczych bibliotekach, między innymi „Pismo PG. Forum Społeczności Akademickiej”, w AGH, Politechnice Łódzkiej, Politechnice Świętokrzyskiej, „Nasza Politechnika. Miesięcznik Politechniki Krakowskiej im. Tadeusza Kościuszki” Politechnice Świętokrzyskiej, „Politechnika Częstochowska. Pismo Środowiska Akademickiego” Politechnice Świętokrzyskiej, „Uniwersytet Zielonogórski. Miesięcznik Społeczności Akademickiej” Politechnice Łódzkiej. Jak wskazuje analiza, długi okres publikowania czasopism, na przykład: „Życie Uczelni. Biuletyn Informacyjny Politechniki Łódzkiej” (1984-), „Pryzmat. Pismo Informacyjne Politechniki Wrocławskiej” (1991-2013 wersja drukowana), czy „Indeks. Pismo Politechniki Świętokrzyskiej w Kielcach” (1992-), nie powoduje, że znajdują się one w kolekcjach innych bibliotek. Ustalono również, że Biblioteka Politechniki Świętokrzyskiej przechowująca w zbiorach najwięcej tytułów innych uczelni, jednocześnie jako jedyna wśród badanych bibliotek posiada czasopisma swojej macierzystej uczelni. W praktyce kolekcje dostępnych tytułów mogą wyglądać inaczej, bowiem brak tytułu w katalogu komputerowym nie zawsze oznacza jego brak w bibliotece. Niektóre biblioteki nie 
opracowują czasopism informacyjnych innych uczelni w katalogu, a jedynie przechowują je przez krótki okres czasu, od roku do trzech lat.

W odróżnieniu od katalogów komputerowych, zasoby biblioteczne akademickich czasopism informacyjnych zarejestrowane w bibliotekach cyfrowych są dostępne w pełnym tekście, można je wyszukiwać dzięki serwisowi Federacji Bibliotek Cyfrowych. Ogółem siedemnaście spośród badanych bibliotek ${ }^{19}$ tworzy lub współtworzy bibliotekę cyfrową, w tym Politechnika Krakowska repozytorium zawierające zasoby biblioteki cyfrowej, jak wspomniano wcześniej.

W wyniku przeglądu bibliotek cyfrowych i Repozytorium PK ustalono, że w dziewięciu bibliotekach udostępniono tytuł macierzystej uczelni, w kompletnym zasobie: „Pismo PG. Forum Społeczności Akademickiej” w Pomorskiej Bibliotece Cyfrowej, „Biuletyn Informacyjny Politechniki Lubelskiej” w Bibliotece Cyfrowej Politechniki Lubelskiej, „Życie Uczelni. Biuletyn Informacyjny Politechniki Łódzkiej” w Łódzkiej Regionalnej Bibliotece Cyfrowej CYBRA. Ponadto część ACI było dostępne w kolekcji niekompletnej: od początku ukazywania się do 2013 nr 2 - „Uniwersytet Zielonogórski. Miesięcznik Społeczności Akademickiej” w Zielonogórskiej Bibliotece Cyfrowej, od początku ukazywania się do 2013 nr 260 - „Pryzmat. Pismo Informacyjne Politechniki Wrocławskiej” w Dolnośląskiej Bibliotece Cyfrowej, od 2000 nr 89 do 2013 nr 238 - „Wiadomości Uczelniane Politechniki Opolskiej” w Dolnośląskiej Bibliotece Cyfrowej, do 2012 nr 50 - „Na Temat. Pismo Politechniki Koszalińskiej” w Bibliotece Cyfrowej Politechniki Koszalińskiej, pojedyncze wybrane teksty z roczników 2010, 2012 - „Biuletyn Politechniki Śląskiej” w Bibliotece Cyfrowej Politechniki Śląskiej oraz „Nasza Politechnika. Miesięcznik Politechniki Krakowskiej im. Tadeusza Kościuszki" pojedyncze wybrane teksty z rocznika 2012 w Repozytorium PK. Można wnioskować, że w oparciu o dostępny w bibliotece kompletny zasób, tytuł „Uniwersytet Zielonogórski. Miesięcznik Społeczności Akademickiej” zostanie uzupełniony o najnowsze roczniki w bibliotece cyfrowej.

Udostępnione pojedyncze pliki PDF to głównie teksty informujące o obowiązujących w uczelni zasadach zamieszczania prac w Śląskiej Bibliotece Cyfrowej ${ }^{20} \mathrm{i}$ Repozytorium $\mathrm{PK}^{21}$ oraz zachęcające autorów do ich składania.

\footnotetext{
${ }^{19}$ Biblioteki: AGH - ABC Kraków; Biblioteka P. Wrocławskiej, P. Opolska - Dolnośląska Biblioteka Cyfrowa; P. Białostocka - Podlaska Biblioteka Cyfrowa; P. Częstochowska, ATH w Bielsku Białej - Śląska Biblioteka Cyfrowa; P. Gdańska - Pomorska Biblioteka Cyfrowa; P. Koszalińska - Biblioteka Cyfrowa P. Koszalińskiej; P. Krakowska - Repozytorium PK; P. Lubelska - Biblioteka Cyfrowa P. Lubelskiej; P. Łódzka - Łódzka Regionalna Biblioteka Cyfrowa CYBRA; P. Poznańska -Wielkopolska Biblioteka Cyfrowa; P. Sląska - Biblioteka Cyfrowa P. Śląskiej; P. Warszawska - Biblioteka Cyfrowa P. Warszawskiej; UTP w Bydgoszczy - Kujawsko-Pomorska Biblioteka Cyfrowa; UZ - Zielonogórska Biblioteka Cyfrowa; ZUT w Szczecinie - ZBC Pomerania.

${ }^{20}$ Zob. też wersję papierową: K. Zioło, Biblioteka Cyfrowa PŚ, „Biuletyn Politechniki Śląskiej” 2010, nr 6/7 (208-209), s. 29.
} 
Rozwiązaniem ułatwiającym dostęp do czasopism są także linki do poszczególnych tytułów, znajdujące się bezpośrednio na stronach WWW bibliotek. Analiza danych z tych stron wykazała, że tylko tytuł publikowany w macierzystej uczelni był dostępny ogółem w pięciu bibliotekach: Politechniki Śląskiej, Politechniki Świętokrzyskiej, UTH w Radomiu (na stronie głównej kompletny zasób); WAT w Warszawie (w wykazie czasopism prenumerowanych zasób od 2003 i w dziale „O bibliotece” w linku „Biblioteka w Głosie Akademickim" (zawiera teksty opublikowane w okresie styczeń-czerwiec 2014); Politechniki Poznańskiej (w zakładce „O bibliotece” w linku „Publikacje o Bibliotece Politechniki Poznańskiej i bibliotekarzach", obejmuje niektóre pełne teksty w rocznikach: 1995, 1997-2000, 2004-2007, 2013 oraz kolekcję pełnych tekstów w publikacji Hanny Nowickiej „O czym piszemy w Głosie Politechniki. Artykuły i informacje bibliotekarzy PP w latach 1995$2007 ")^{22}$.

Z porównania zasobów w bibliotekach cyfrowych z kolekcjami na stronach WWW bibliotek wynika, że biblioteki udostępniające archiwum ACI w bibliotece cyfrowej nie zamieszczają go na swojej stronie internetowej. Wśród bibliotek rekomendujących tytuł online znalazły się tylko te, które nie uczestniczą w projekcie biblioteki cyfrowej oraz te, które nie udostępniły archiwum tytułu lub udostępniły tylko pojedyncze pliki PDF.

\section{Wnioski}

Biblioteki stanowią podstawowe miejsce udostępniania archiwum czasopism informacyjnych macierzystej uczelni w wersji drukowanej. Część z nich zamieszcza $\mathrm{w}$ katalogach komputerowych odsyłacze do zasobów internetowych, a kompletne roczniki bądź wybrane pojedyncze teksty w bibliotece cyfrowej/repozytorium. Pięć bibliotek spośród badanych, które nie posiadają oferty w bibliotece cyfrowej zamieszczają linki do cyfrowego archiwum na stronie WWW biblioteki. Kolekcje te jednak podlegają ciągłym zmianom.

Wydawnictwa uczelniane przejmują zadanie długoterminowego archiwizowania zasobów cyfrowych. Coraz częściej ACI publikowane są w postaci portalu internetowego, co skraca znacząco czas udostępniania nowych treści odbiorcom. Zawartość bazy i portal są zintegrowane w jeden zasób, a to umożliwia wspólne przeglądanie treści za pomocą wyszukiwarki.

Od 2013 r. ACI: „Biuletyn Politechniki Warszawskiej”, „Pryzmat. Pismo Informacyjne Politechniki Wrocławskiej”, „Wiadomości Uczelniane Politechniki Opolskiej”, „Z Życia Uniwersytetu. Czasopismo Uniwersytetu Technologiczno-Humanistycznego im. Kazimierza Pułaskiego w Radomiu” ukazują się

${ }^{21}$ Zob. też wersję papierową: D. Buzdygan, Promuj własna twórczość naukowa!!, „Nasza Politechnika. Miesięcznik Politechniki Krakowskiej im. Tadeusza Kościuszki” 2012, nr 10 (110), s. 16.

${ }^{22}$ H. Nowicka, O czym piszemy... 
wyłącznie online. Ponieważ czasopisma coraz częściej wydawane są w wersji elektronicznej, będzie to powodować brak tytułów uczelnianych w bibliotekach oraz ich nieobecność w bibliotekach cyfrowych. Katalog komputerowy stał się niewystarczającym źródłem informacji o czasopismach uczelnianych. K. Coyle i D. Hillmann podkreślają, że jest również niewystarczającym narzędziem informacji o innych zasobach naukowych online, pisząc „Changes in the context in which libraries function have brought the library and its catalog to a crisis point. (...) The effect of computers and networks of information resources on the mission of libraries is still being debated, but the very existence of libraries in the future rides on their ability to respond to today's - and tomorrow's technology"23.

Zapobieganie wykluczeniu w procesie udostępniania czasopism uczelnianych stanowi szczególne wyzwanie dla współczesnych bibliotek. Archiwizowanie i opracowanie ACI od zawsze było misją biblioteki akademickiej. Jednym z czynników aktywności bibliotek jest ,,[... korzystanie z rozproszonych zasobów w realizacji nowych usług oraz realizacja projektów, w które zaangażowanych jest wielu partnerów" ${ }^{24}$, na przykład poprzez tworzenie bazy danych.

Upowszechnianie zawartości akademickich czasopism informacyjnych jest konieczne, ponieważ są doskonałym narzędziem dokumentowania ważnych wydarzeń z życia uczelni i jej pracowników, promocji uczelni i bibliotek oraz edukacji w zakresie rozwoju bibliotek polskich.

\section{Bibliografia}

Biblioteka bez papierowej ksiązki, ale innych tu nie braknie, „Pryzmat. Wiadomości Politechniki Wrocławskiej” 29.04.2014, Aktualizacja: 07.05.2014 16:33, [dostęp: 15.08.2014], http:// www.pryzmat.pwr.edu.pl/wiadomosci/702.

Bibliotek@Cyfrowa Politechniki Krakowskiej, [dostęp: 15.08.2014], http://www.biblos. pk.edu.pl/bc.

Buzdygan D., Promuj własną twórczość naukową!, , Nasza Politechnika. Miesięcznik Politechniki Krakowskiej im. Tadeusza Kościuszki” 2012, nr 10 (110), s. 16.

Co nowego w...Bibliotece, Oprac.: E.R., „Życie Uczelni. Biuletyn Informacyjny Politechniki Łódzkiej” 1996, nr 40, s. 5.

Coyle K., Hillmann D., Resource Description and Access (RDA), Cataloging Rules for the $20^{\text {th }}$ Century, "D-Lib Magazine”, vol. 13, no 1/2 (January/February 2007), [dostęp: 15.08.2014], http://www.dlib.org/dlib/january07/coyle/01 coyle.html.

Gajda J., Biblioteka Politechniki Lubelskiej. Milion dokumentów w polskich bibliotekach cyfrowych, ,Biuletyn Informacyjny Politechniki Lubelskiej” 2012, nr 2 (30), s. 16-17.

Ganińska H., Co nowego w Bibliotece Gtównej, „Głos Politechniki. Pismo Politechniki Poznańskiej” 1997, nr 2-3, s. 12-13.

Jarkiewicz K., Informator o Redakcjach gazet akademickich w 2012 roku, „Forum Bibliotek Medycznych" 2012, R. 5, nr 1 (9), s. 547-590.

${ }^{23}$ K. Coyle, D. Hillmann, Resource Description and Access (RDA), Cataloging Rules for the $20^{\text {th }}$ Century, "D-Lib Magazine", vol. 13, no $1 / 2$ (January/February 2007), [dostęp: 15.08.2014], http://www.dlib.org/dlib/january07/coyle/01 coyle.html.

${ }^{24} \mathrm{M}$. Nahotko, Naukowe czasopisma ..., s. 152. 
Knop U., Polskie czasopisma ogólnodostępne online w katalogach OPAC i na stronach WWW bibliotek wyżsych uczelni technicznych - rozpoznanie wstępne, „Bibliotheca Nostra” 2014, nr 1 (35), s. 62-72.

Myszkowski P., Szafrański L., Sposób prezentacji czasopisma w bibliotece cyfrowej, [w:] Opracowanie czasopism ukazujacych się przed II wojna światowa w kontekście ich publikacji w bibliotece cyfrowej. Konferencja, Kraków, Biblioteka Jagiellońska, 17 listopada 2011 r., [dostęp: 15.08.2014], http://jbc.bj.uj.edu.pl/dlibra/publicationid=92556 $\&$ from $=\&$ dirids $=1 \&$ tab $=1 \& \mathrm{l}=1 \& \mathrm{QI}=$.

Nahotko M., Naukowe czasopisma elektroniczne, Warszawa 2007.

Narloch A., Skrodzka J., BazTech - baza indeksujaca polskie czasopisma z zakresu nauk technicznych, „Forum Uczelniane. Pismo Zachodniopomorskiego Uniwersytetu Technologicznego w Szczecinie" 2014, nr 3 (23), s. 26-28.

Nowe oblicze Biblioteki Głównej AGH. Temat wydania, „Biuletyn AGH” 2014, nr 75, s. 2, 4-15.

Nowicka H., O czym piszemy w ,Głosie Politechniki”. Artykuly i informacje bibliotekarzy PP w latach 1995-2007, Poznań 2008, (Zapiski Biblioteki Głównej Politechniki Poznańskiej; nr 14), [dostęp: 15.08.2014], http://library.put.poznan.pl/doc/publik/zapiskizapiski14.html.

Pawelec I., Celoch H., Biblioteka Glówna, „Biuletyn Informacyjny Politechniki Lubelskiej” 1997, nr 1, s. 36.

Piwońska I., Peszel A., Koniec wieńczy dzieło, „Głos Akademicki Wojskowej Akademii Technicznej" 2014, nr 1 (214), s. 40.

Rohleder R., Konsorcjum DBC - wspótpraca bibliotek przy tworzeniu kolekcji cyfrowych, zbiory medyczne, „Forum Bibliotek Medycznych” 2010, R. 3, nr 2 (6), s. 209-218.

Strumiłło A., Bibliografia czasopism akademickich o profilu informacyjnym (1989-2012), „Forum Bibliotek Medycznych” 2012, R.5, nr 1 (9), s. 591-624.

Swoboda I., Frączek R., Dokumenty elektroniczne w OPAC bibliotek polskich. Komunikat z badań, „Praktyka i Teoria Informacji Naukowej i Technicznej” 2009, T. 17, nr 4 (68), s. $30-37$.

Szarski H., Komputeryzacja systemu biblioteczno-informacyjnego PWr, „Pryzmat. Pismo Informacyjne Politechniki Wrocławskiej" 2003, nr 171, s. 46-47.

Szczygłowska L., Komputeryzacja Biblioteki Głównej Politechniki Częstochowskiej w systemie $A P I S-Z B$, , Politechnika Częstochowska” 2000, R. 4, nr 13, s. 9-11.

Wałek A., Biblioteka cyfrowa jako typ otwartego repozytorium (na przykładzie Dolnoślaskiej Biblioteki Cyfrowej), [w:] Otwarte zasoby wiedzy. Nowe zadania uczelni i bibliotek w rozwoju komunikacji naukowej. Materiaty konferencyjne, Kraków-Zakopane, 15-17 czerwca 2011, Kraków 2011, s. 125-137.

Wałek A., Strony WWW bibliotek jako element promocji i narzędzie komunikacji z użytkownikiem, „Fides. Biuletyn Bibliotek Kościelnych” 2014, nr 1 (38), s. 109-118.

Zioło K., Biblioteka Cyfrowa PŚ, „Biuletyn Politechniki Śląskiej” 2010, nr 6/7 (208-209), s. 29. 